\title{
Article \\ Wooden Additional Floors in Old Apartment Buildings: Perspectives of Housing and Real Estate Companies from Finland
}

\author{
Markku Karjalainen, Hüseyin Emre Ilgın * and Dennis Somelar
}

Citation: Karjalainen, M.; Ilgın, H.E.; Somelar, D. Wooden Additional Floors in Old Apartment Buildings: Perspectives of Housing and Real Estate Companies from Finland. Buildings 2021, 11, 316. https:// doi.org/10.3390/buildings11080316

Received: 16 June 2021

Accepted: 19 July 2021

Published: 22 July 2021

Publisher's Note: MDPI stays neutral with regard to jurisdictional claims in published maps and institutional affiliations.

Copyright: (c) 2021 by the authors. Licensee MDPI, Basel, Switzerland. This article is an open access article distributed under the terms and conditions of the Creative Commons Attribution (CC BY) license (https:/ / creativecommons.org/licenses/by/ $4.0 /)$.
School of Architecture, Faculty of Built Environment, Tampere University, FI-33014 Tampere, Finland; markku.karjalainen@tuni.fi (M.K.); dennis.somelar@tuni.fi (D.S.)

* Correspondence: emre.ilgin@tuni.fi

\begin{abstract}
This paper examined various stages and advantages of wooden additional floors from the perspective of Finnish housing and real estate companies through interviews with professionals involved in these projects. Main findings highlighted: (1) commercial conditions should be carefully analyzed for return on investment; (2) city plan change and the presence of a potential contractor and an expert were generally considered important issues; (3) considerations regarding city planning, parking spaces, load-carrying capacity, and new building codes were highlighted as critical factors for feasibility study; (4) existing building regulations and building rights regarding the subscription fee and tax issues should be considered during project planning; (5) city plan change and building rights with different tendering conditions were reported as important parameters in implementation planning; (6) an efficient flow of information between the parties involved was vital to the successful progress of the construction phase. Wooden additional floor construction, which requires commitment, investment, and cooperation between interested parties, has great potential regarding construction technology and contracting mechanisms. Additionally, this sustainable approach has many advantages concerning the environment, economy, energy efficiency, and aesthetics. In this sense, it is believed that this study will contribute to the diffusion of wooden additional floor construction in other countries besides Finland.
\end{abstract}

Keywords: wood; additional floor construction; sustainability; housing company; real estate company; Finland

\section{Introduction}

The Energy Roadmap 2050 stated that it is very important to decarbonize the increasing share of renewable energy and use energy more efficiently [1]. In recent decades, building regulations have been renewed in Finland so that they have guided new ways of construction to become increasingly energy-efficient [2,3]. Most of Finland's building stock was built before the 1990s, and this stock is poor in energy efficiency compared to new buildings, and most of the building stock is coming into the era of renovation [4,5]. Older building stock, especially apartment buildings built in the 1960s-1980s require major energy upgrades to approach a sustainable and carbon-neutral built environment [6,7].

Housing and real estate companies play a major role in repairing and maintaining old apartment buildings [8]. There are about 62,000 apartment buildings in Finland, in which about half of the Finnish population lives [5]. Maintenance and development of apartment buildings are often the responsibility of housing or real estate companies that need financing tools to renovate and refine their properties [8,9].

Renovation of real estate by increasing accessibility and energy efficiency requires a lot of capital and government subsidies [10]. Moreover, renovation projects include an excessive amount of work and strong coordination from building managers and housing companies, as well as inhabitants [11]. On a practical application level, the renovation 
of apartment buildings is a slow and expensive process that causes dirt and disturbs building occupants $[12,13]$. This is because renovation projects in Finland typically apply operational models designed for new construction [14]. Renovation of apartment buildings uses methods designed for new buildings, and much of the work is done on-site, disrupting life for residents, and the area near the construction site [15].

An emerging alternative to cover renovation costs is additional construction. As an efficient form of additional space, additional floors are used to fund property development and renovation measures [14]. Additional floors essentially directly increase the energy efficiency of the building, but also indirectly, for example by using revenues from it for energy renovation. It is worth mentioning here that energy-related measures help increase the cost effectiveness of the entire renovation process and the maintenance of buildings [16-18]. Furthermore, revenue from additional floors can be used to finance the construction of a retrofit elevator to the property or new/expanded balconies, thus improving the accessibility and living comfort of the building.

When renovations are accompanied by building rights or the construction of additional floors where space can be sold or leased, the cost of the renovation can be offset by the income from this additional space. In city centers where the unit price per square meter is higher, a housing company can make a profit by demolishing the old building and rebuilding new larger building in its place, while a reasonable amount of additional construction in an apartment neighborhood can hardly cover all the renovation costs incurred by the housing company. However, the income from additional floors can make a significant contribution - this is crucial to the company's decision to do extensive renovation work rather than demolishing the building.

The characteristics of concrete-framed apartment blocks built between the 1960s and 1980s often allow the construction of additional floors using lightweight structures. Lightweight structured additional floors can be constructed using wood as load-bearing structures, which is also permitted by Finland's new national fire regulations [14]. These blocks also often have flat roofs, which makes it easy to add a floor or floors both architecturally and technically. Considering sustainable construction, the materials used in renovation should be renewable, recyclable, long-lasting, and their production should have features that consume only the minimum amount of energy and produce as little emission as possible $[19,20]$. Research showed that wood products are associated with much less greenhouse gas emissions over their lifetime than traditional building materials such as concrete and steel [21-23]. Furthermore, the use of wood offers prefabricated and lightweight solutions with a wide variety of thermal insulation and sizing options to meet specific needs [24,25].

The literature to date lacks a comprehensive understanding of wooden additional floors and the application of such structures, especially in the residential construction sector. Overall, the objective of this paper was to map out different stages and benefits of wooden additional floor projects from the standpoint of housing and real estate companies as comprehensively as possible through literature and interviews.

This study will help housing and real estate companies develop strategies for wooden additional floors in renovation projects by highlighting the benefits and opportunities of this structure. In this research, wood refers to engineered wood products [26,27] such as cross-laminated timber (CLT-a prefabricated multi-layer EWP, manufactured from at least three layers of boards by gluing their surfaces together with an adhesive under pressure), laminated veneer lumber (LVL - made by bonding together thin vertical softwood veneers with their grain parallel to the longitudinal axis of the section, under heat and pressure), and glue-laminated timber (glulam) (GL—made by gluing together several graded timber laminations with their grain parallel to the longitudinal axis of the section).

The remainder of this paper is structured as follows: First, an explanation of the research method used in the study is given. This is followed by findings of wooden additional floor construction and interviews with professionals who have been involved in additional floor construction. Finally, the results of the study are presented. 


\section{Research Method}

This study was carried out mainly as a literature review including international peerreviewed journals and similar research projects, supported by materials collected during the PKRKP project, as well as interviews with professionals who have been involved in additional floor construction. The PKRKP project (Construction of Wooden Apartment Buildings for Growth in Pirkanmaa between 2019 and 2021) involves Metsäkeskus and the City of Tampere, as well as 14 municipalities and 15 companies in the Pirkanmaa region (Finland). The main emphasis of the project was to increase the competitiveness of wooden apartment buildings and to demonstrate the potential of wood in energy enhancement and the construction of additional floors in suburban apartments.

In this research, semi-structured interviews (see Appendix A) were applied as the best method for collecting data because the process allows interviewer and participant interactions and different perspectives to encourage the creation of new themes beyond what was initially discovered [28]. These interviews were conducted during the PKRKP project with 7 construction professionals who were mainly part of a wooden additional floor construction project and one housing company was also interviewed, which had a preliminary review of an additional floor construction project (see Table 1). This housing company was asked what an additional floor construction project looked like from their point of view and which parts of the project would be difficult to find out or outline without outsourcing.

Table 1. Interviewees by their position, experience in additional floor construction, and organization type.

\begin{tabular}{|c|c|c|c|c|}
\hline & Interviewee 1 & Interviewee 2 & Interviewee 3 & Interviewee 4 \\
\hline Position & $\begin{array}{l}\text { Property } \\
\text { Development } \\
\text { Manager }\end{array}$ & $\begin{array}{l}\text { Additional } \\
\text { floor construction } \\
\text { consultant }\end{array}$ & City planner & $\begin{array}{l}\text { Project director, } \\
\text { City planning }\end{array}$ \\
\hline $\begin{array}{l}\text { Experience in } \\
\text { additional floor } \\
\text { construction }\end{array}$ & $\begin{array}{l}\text { Involvement in } \\
\text { two additional } \\
\text { floor projects }\end{array}$ & $\begin{array}{l}\text { Involvement in one } \\
\text { additional floor } \\
\text { project that was built, } \\
\text { and in various other } \\
\text { projects } \\
\text { in the early stages }\end{array}$ & $\begin{array}{l}\text { Promotion of city } \\
\text { extension projects } \\
\text { and additional floors } \\
\text { in various city } \\
\text { planning } \\
\text { development projects }\end{array}$ & $\begin{array}{l}\text { Promotion of city } \\
\text { extension projects } \\
\text { and additional floors } \\
\text { in various city } \\
\text { planning } \\
\text { development projects }\end{array}$ \\
\hline \multirow[t]{2}{*}{ Organization type } & Contractor & $\begin{array}{l}\text { Consultant, } \\
\text { Developer }\end{array}$ & Municipality & Municipality \\
\hline & Interviewee 5 & Interviewee 6 & Interviewee 7 & Interviewee 8 \\
\hline Position & $\begin{array}{l}\text { Project director, } \\
\text { City planning }\end{array}$ & $\begin{array}{l}\text { CEO, Associate, } \\
\text { Architect }\end{array}$ & $\begin{array}{l}\text { CEO, Associate, } \\
\text { housing manager }\end{array}$ & $\begin{array}{l}\text { Member of the } \\
\text { Board of Directors } \\
\text { of a housing company }\end{array}$ \\
\hline $\begin{array}{l}\text { Experience in } \\
\text { additional floor } \\
\text { construction }\end{array}$ & $\begin{array}{l}\text { Promotion of city } \\
\text { extension projects and } \\
\text { additional floors } \\
\text { in various city } \\
\text { planning } \\
\text { development projects }\end{array}$ & $\begin{array}{l}\text { Involvement in } \\
\text { one additional floor } \\
\text { project that was built, } \\
\text { and in various other } \\
\text { projects } \\
\text { in the early stages }\end{array}$ & $\begin{array}{l}\text { Involvement in two } \\
\text { additional floor } \\
\text { projects that were built, } \\
\text { or about to be built, } \\
\text { and in various other } \\
\text { projects } \\
\text { in the early stages }\end{array}$ & $\begin{array}{l}\text { Preliminary } \\
\text { examination of the } \\
\text { possibilities of } \\
\text { additional floor } \\
\text { construction in the } \\
\text { property under } \\
\text { management }\end{array}$ \\
\hline Organization type & Municipality & Architectural design & Housing manager & Housing company \\
\hline
\end{tabular}

Efforts were made to name the phases of additional floor projects to correspond to the marketing and communication of commercial operators. In this way, the names of the stages correspond to the most common possible terminology currently used in the activities of professionals consulting on additional construction. It was hoped that this would lead to a result that would provide a framework for the clearest possible communication between housing or real estate companies and commercial operators. 
Thus, interviews highlighted key points in the four phases of additional floor construction (Figure 1) - (1) feasibility study; (2) project planning; (3) implementation planning; (4) construction-detailed in the findings section along with general critical issues.

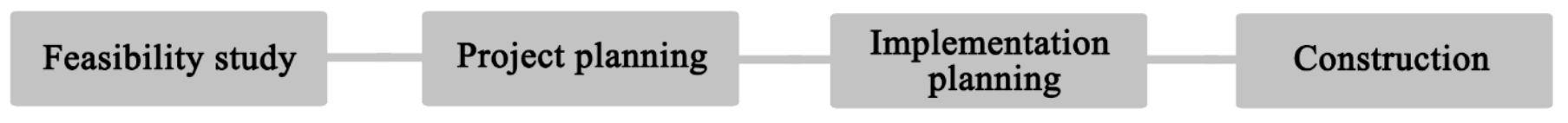

Figure 1. Four phases of wooden additional floor construction.

\section{Findings}

\subsection{Wooden Additional Floor Construction}

When the roof shape of buildings changes, height increases, and the number of floors of buildings increases, the terms additional floor, roof, or elevation construction are used (Figure 2). The additional floor construction is one of the ways to improve the property by additional construction, and the project may require a change in the city plan to be completed [29] and in the case of Tampere, Finland they mainly have [30].
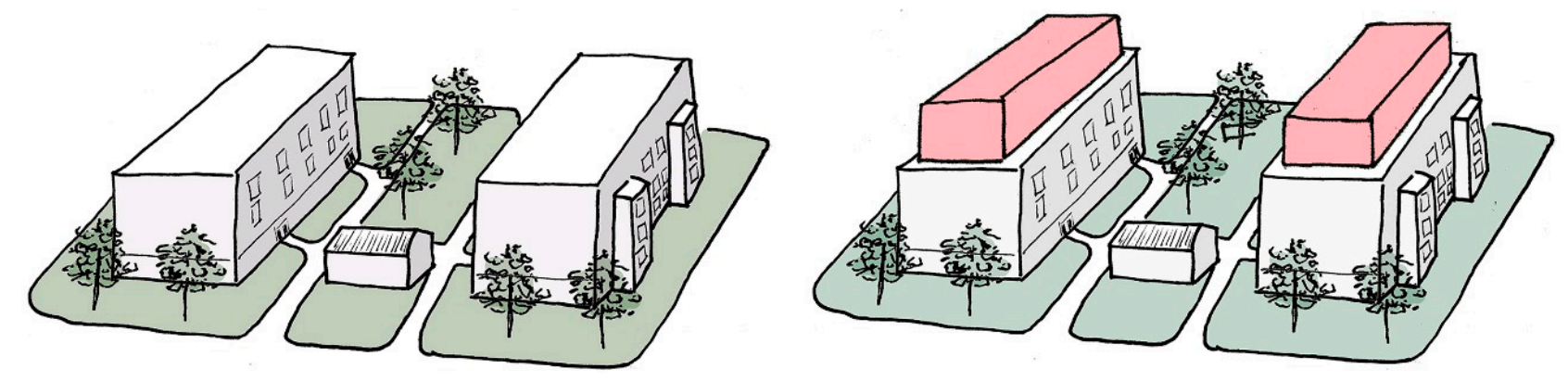

Figure 2. Additional floor construction.

The advantages of additional floor construction can be summarized as follows:

(a) additional floor construction allows the building stock to be developed beneficially, increasing the income of the property owners as an efficient and environmentally friendly construction method. Renovation and upgrading of existing buildings are the most advantageous in terms of carbon footprint compared to demolition and new construction [31]. In the comparison study by Huuhka et al. [31], renovation and upgrading operations with additional floors were more than $20 \%$ lower in terms of a carbon footprint than demolition and new construction;

(b) additional floor construction provides short-term income to housing companies by selling the building rights or areas of the additional floors. Although the construction cost of the additional floor is around EUR $3285 / \mathrm{m}^{2}$ - this is about 1.5 times more expensive than the construction of new buildings-[32], revenues from additional floors can be used to finance the renovation of the existing property, such as the renovation of an elevator to improve the accessibility and commercial conditions of the building. This ensures a profitable investment in the long term [14];

(c) additional floors do not significantly increase the overall energy consumption of the upgraded building, although they substantially increase the total floor area. Moreover, as energy-efficient passive structures, additional floors can considerably increase the energy efficiency of old buildings, especially if upper floors have not been renovated for a long time [33];

(d) additional floors improve the image and appearance of individual buildings as well as spaces. By modernizing the design language, they can have a significant impact on the architectural values of an existing building. 
On the other hand, additional floor construction is now possible with modern construction methods using various lightweight prefabricated elements. For example, load-bearing structures of apartment buildings, especially those built in Finland in the 1960s and 1980s, can usually bear 1-2 additional light structured floors [34].

The selection of materials used in renovation is also important in terms of the sustainable ecology of the business [35]. Materials used in renovations should be renewable, recyclable, long-lasting, and their production should only consume the minimum amount of energy and generate as few emissions as possible [14]. Studies show that wood products are associated with much less greenhouse gas emissions over their lifetime than traditional building materials such as concrete and steel [36-42].

Prefabricated wooden frame solutions are lightweight, the degree of thermal insulation can be selected freely, and their dimensions can be altered-the adaptation of individual elements can also be designed and constructed to meet specific needs [25,43-45]. As a part of the prefabrication process, facade components-windows, doors, and cladding-can be integrated into the units and interior cladding of prefabricated units can be made if desired $[45,46]$. The use of prefabricated wooden elements in the construction of additional floors accelerates the construction phase, while at the same time increasing the carbon storage capacity of already-built residential areas and supporting the quest for a sustainable built environment by building from renewable and low-emission materials.

Wooden additional floor construction in this study was divided into four phases, which are feasibility study, project planning, implementation planning, and construction. In the feasibility study, the conditions for the construction of additional floors are examined and professionals in the construction and real estate industry are contacted. During project planning, the conditions of the project are determined, and the planning of the course and scope of the project starts accordingly. In implementation planning, measures are taken to increase the building right that allows the construction of additional floors and to improve the construction plans. Finally, the construction of additional floor(s) begins.

\subsection{Interviews with Professionals Involved in an Additional Floor Construction}

Findings from interviews with professionals involved in additional floor projects covering the four stages of the whole process are detailed in the sections below. General aspects that require special attention in these projects are as follows:

(a) economic feasibility: this is especially important if the building right is to be sold to an external party constructing additional floors. In case of an incorrect evaluation of the commercial conditions of additional floors, it is difficult to sell the building rights at the desired price and therefore the return of the project is lower than expected. In the worst-case scenario, there is no external party to build an additional floor, in which case the investment cannot be refunded;

(b) city plan change: changing the city plan or granting a deviation from the city plan to increase the right to build on the land affect the property tax amount;

(c) potential contractor: if an external party cannot be found to build additional floors, the project cost suffers, and the maintenance cost of the property increases in the future;

(d) involvement of a specialist: the prerequisites for the success of additional floor projects are raised, especially for a housing company, by assessing and then minimizing risks. There is even a practice in some Finnish cities not to initiate a change in the city plan to allow additional construction unless an expert is involved to introduce the project, or the conditions of the project are adequately explained.

\subsubsection{Feasibility Study Phase}

This phase begins with an assessment of the benefits of additional floors to a particular plot and building, and further steps are detailed in Figure 3. 


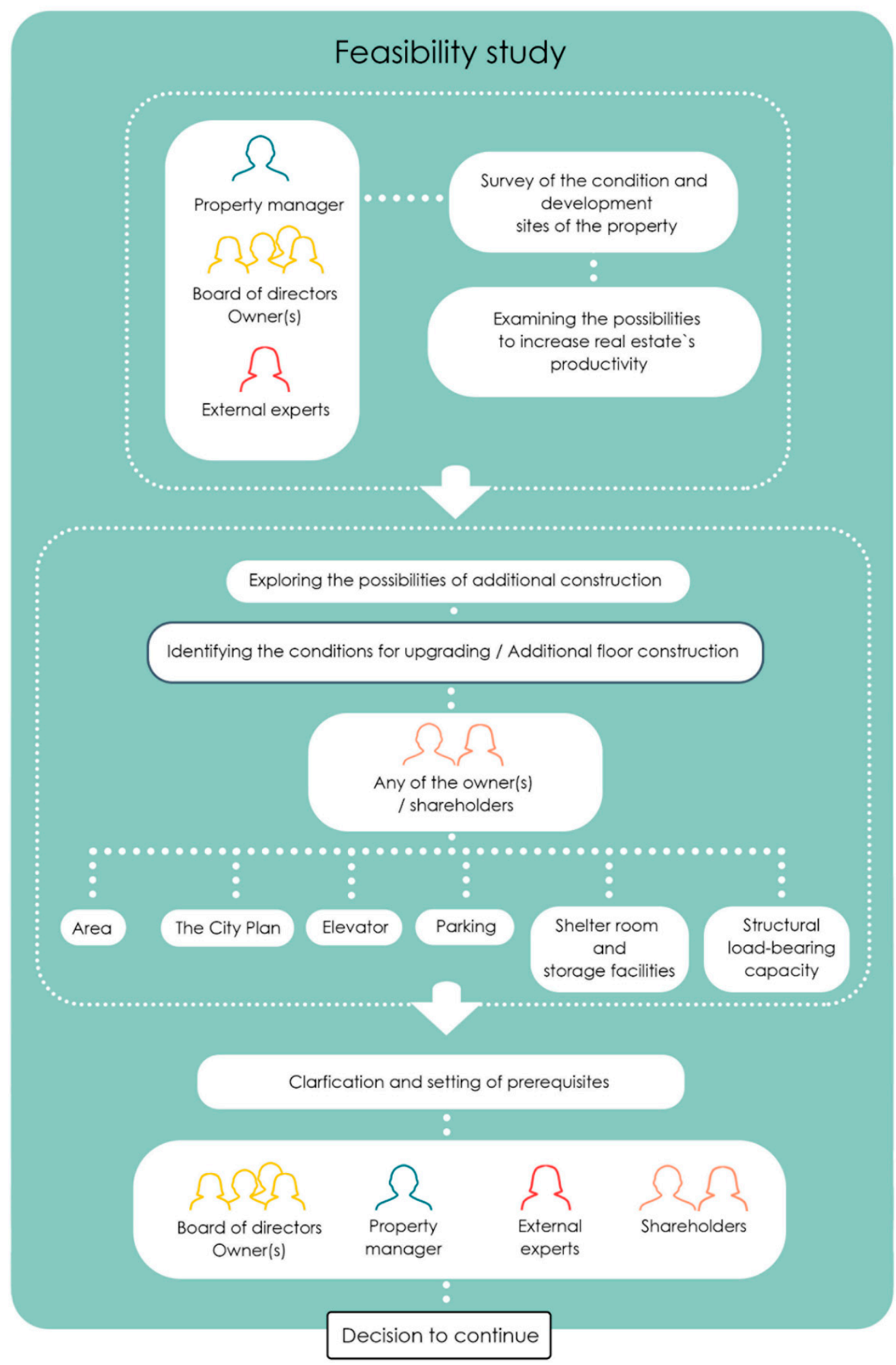

Figure 3. Feasibility study of additional floors.

Critical considerations for the feasibility study phase are as follows:

(a) city planning issues: it is important to contact the city's planning authorities at the start of the feasibility study and to identify the possibilities for permits or deviations from the city plan. Additional floor construction, such as the boundary conditions of the city planning, can also be questioned by the city's building inspectorate or planning authorities at the beginning of the project. City planning issues include, for 
example, how additional floors relate to the surrounding buildings and, if carried out, overshadow, for example, a courtyard or a busy promenade;

(b) parking spaces: with additional floors, the floor area, and the number of residents increase. Parking spaces for new residents and apartments should be defined and built on or near the plot. The number of parking spaces required for the area is determined by the city authorities on a case-by-case basis, and Finland has no national regulation on the number of parking spaces. The number can also be affected by shared cars. Deviations from the amount of parking included in the city plan can be obtained from the building control authority;

(c) information and documentation process: in most cases, the information provided in the drawings may vary from site to site and needs to be reinforced as the project progresses. Completing building drawings can be costly if information needs to be obtained from the municipality's building inspectorate or is indicated, for example, through site visits and measurements. However, it is in the general interest of housing and real estate companies to compile the drawings, as they can also be used for other measures, such as designing facade repairs, retrofitting HVAC systems, or constructing retrofit elevators;

(d) the load-bearing capacity of the existing building: to inspect the structure, the housing or real estate company must compile existing drawings of the building. The loadbearing capacity of the existing framework and foundations can in some cases be calculated directly from the drawings but providing the load-bearing capacity may also require structural analysis. A structural engineer specializing in renovation projects should be commissioned to examine this capacity, but if the site requires a more detailed analysis of the structures, an expert on structures and foundation conditions should also be involved;

(e) existing regulations: the extension of a building is affected by new building regulations and rules, such as accessibility. If an apartment without an elevator is upgraded with additional floors, then retrofit elevators are required in the building to apply the additional floor, as is the case in the City of Helsinki [47]. Retrofit elevators can be built inside an existing ready stairwell or built outside of the building mass and thus incorporated into the architecture of the additional floors (Figure 4).
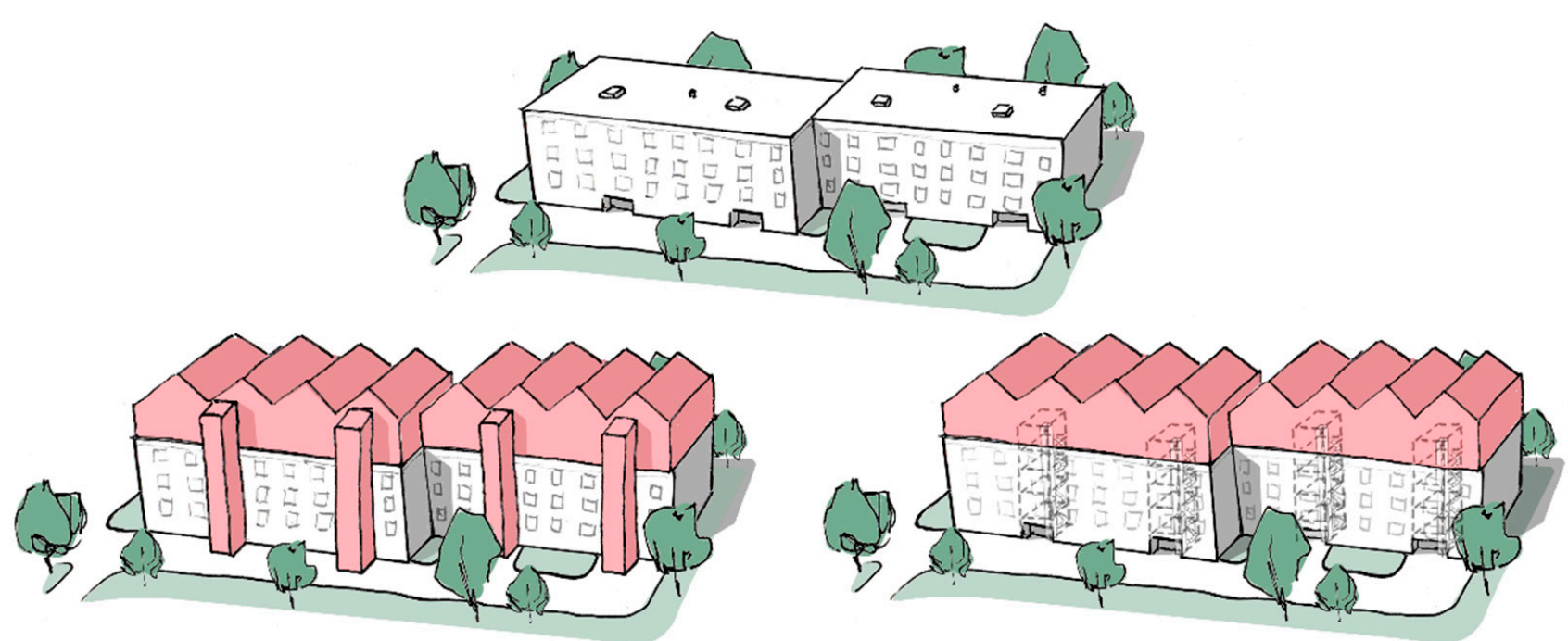

Figure 4. A retrofit elevator for additional floor construction.

\subsubsection{Project Planning Phase}

During this phase, the housing or real estate company starts to draw the mass of the additional floors and determines the course of the project with the help of experts as shown in Figure 5. This is strongly influenced by the form of the company of the 
property owners throughout the project. Real estate companies often build additional floors themselves, while housing companies combine additional floors and shareholders in their own companies and sell the building right to a third-party developer through a share issue.

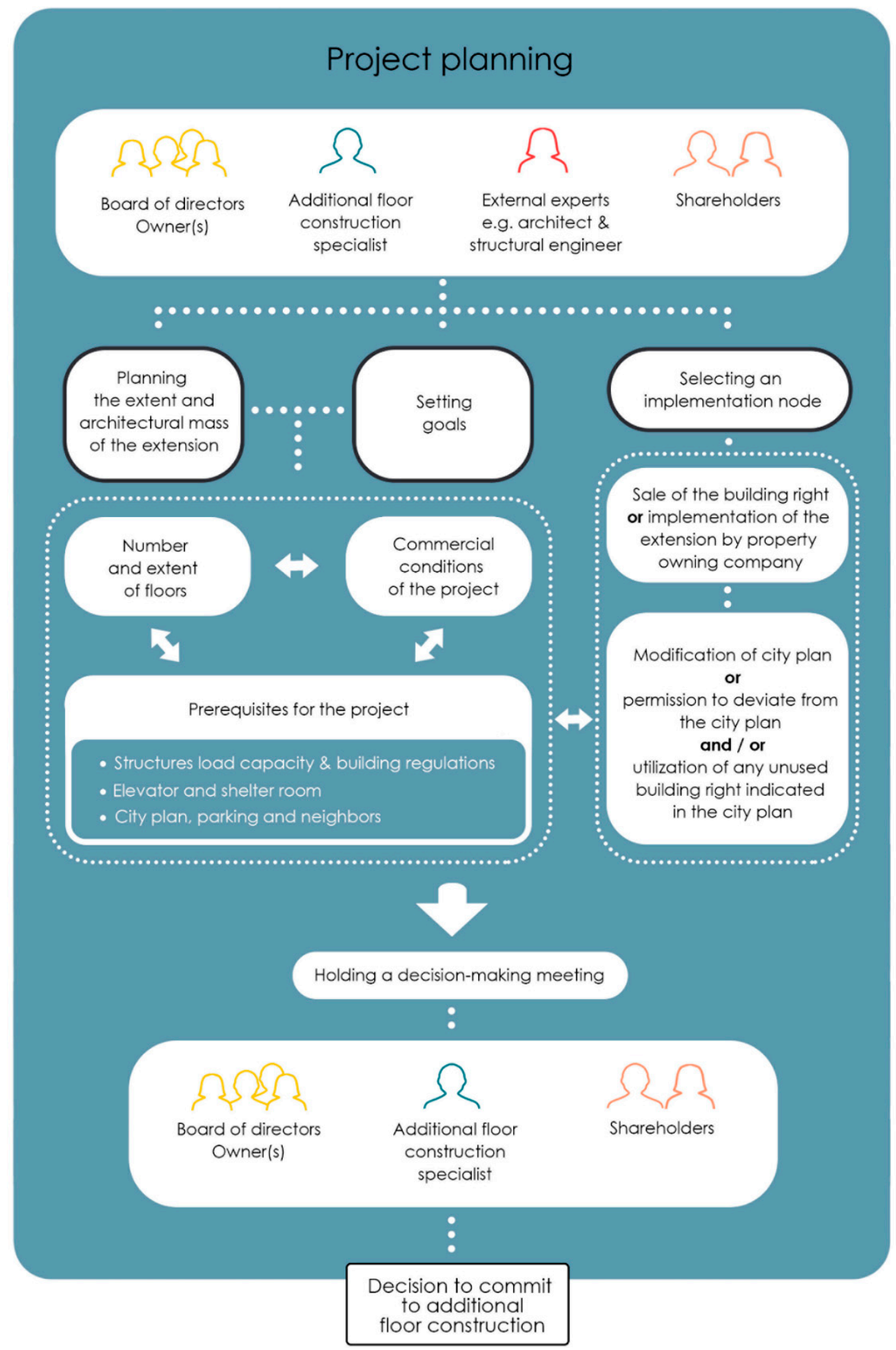

Figure 5. Project planning of additional floors. 
An independent real estate or housing company may also be created for the properties of additional floors, but this option does not provide tax exemption for the income from the sale of building rights and the new company does not provide property maintenance costs and fees. In this option, the housing company does not make any long-term savings that would be possible if the number of shareholders in the company would increase. Critical considerations for the project planning phase are as follows:

(a) the sale of the building right: when an additional extension building right is sold to a third party by issuing shares, a subscription fee is allocated to the shares. Furthermore, separate compensation may be determined in connection with the sale of the building right, which may include the costs and additional floors used to design the project. The flats in the ascending part are associated with an existing company, in this case, the income from the sale of the building right is tax-free income compared to the capital investment. If the implementation of the project is chosen to include a residential increase in an existing company, the company must be prepared to amend its articles of association for a direct issuance of shares;

(b) building regulations: they affect the scope and application of the elevation, regardless of the building material from which the additional floors are constructed, for example in terms of sound and fire performance. Fire regulations should be considered at an early stage, especially when designing a wooden extension, where Finnish fire codes allow the construction of two additional wooden floors. However, vertical extensions with more than two wooden floors can provide fire safety on a case-by-case basis. In this case, modeling is used to gather information about the building that guides the fire design and sizing of building components, where a fire safety expert is needed to support the design. Expanding the design team increases design costs, site official operations, and possibly construction costs, but also allows for increased building rights and therefore the amount of revenue the expansion can generate. As the number of floors and extensions of a building increases to nine stories and above, it likely needs new exits regardless of the additional material for fire safety. This could make several additional floors economically unprofitable, or new exits could have too much of an impact on the building's cityscape; in this case, city authorities may not allow the increase.

\subsubsection{Implementation Planning Phase}

In the implementation planning phase as shown in Figure 6, critical considerations are as follows:

(a) city plan change: for this, the permission of the landowner and material showing the effect of the additional floor on the immediate surroundings of the property is required. Such studies and materials may include, for example, elevation plans and visualizations of their suitability in the immediate environment, a site drawing showing the location of parking lots and the impact on the comfort of courtyard spaces, and possibly an inventory of the building stock. While preparing the city plan, the party initiating the city plan change is obliged to participate in the preparation of such studies. The above-mentioned tasks may be outsourced or carried out by the municipality where the city plan is located. In any case, the party initiating the city plan change is obliged to contribute to the costs incurred;

(b) the building right: in case the building right of the additional floors is sold to an external developer, a tender can be made after the building right has been added to the land. Tender for building right can be started at the projecting stage before the city plan change or permission, however, specifying the city plans and completing the work by the authorized person may increase the value of the building right;

(c) terms and conditions: the company that manages the property to be extended vertically may set conditions for the sale of the building right. The terms and conditions can protect the interests of the company managing the property. Conditions that protect the interests of the company may include restrictions such as what type of con- 
tractor must be used to build the upgrade and demonstrating that the contractor has adequate experience and professionalism. Moreover, these conditions may include payment procedures for the purchase of a building right or minimum specifications for warranty periods provided by contractors.

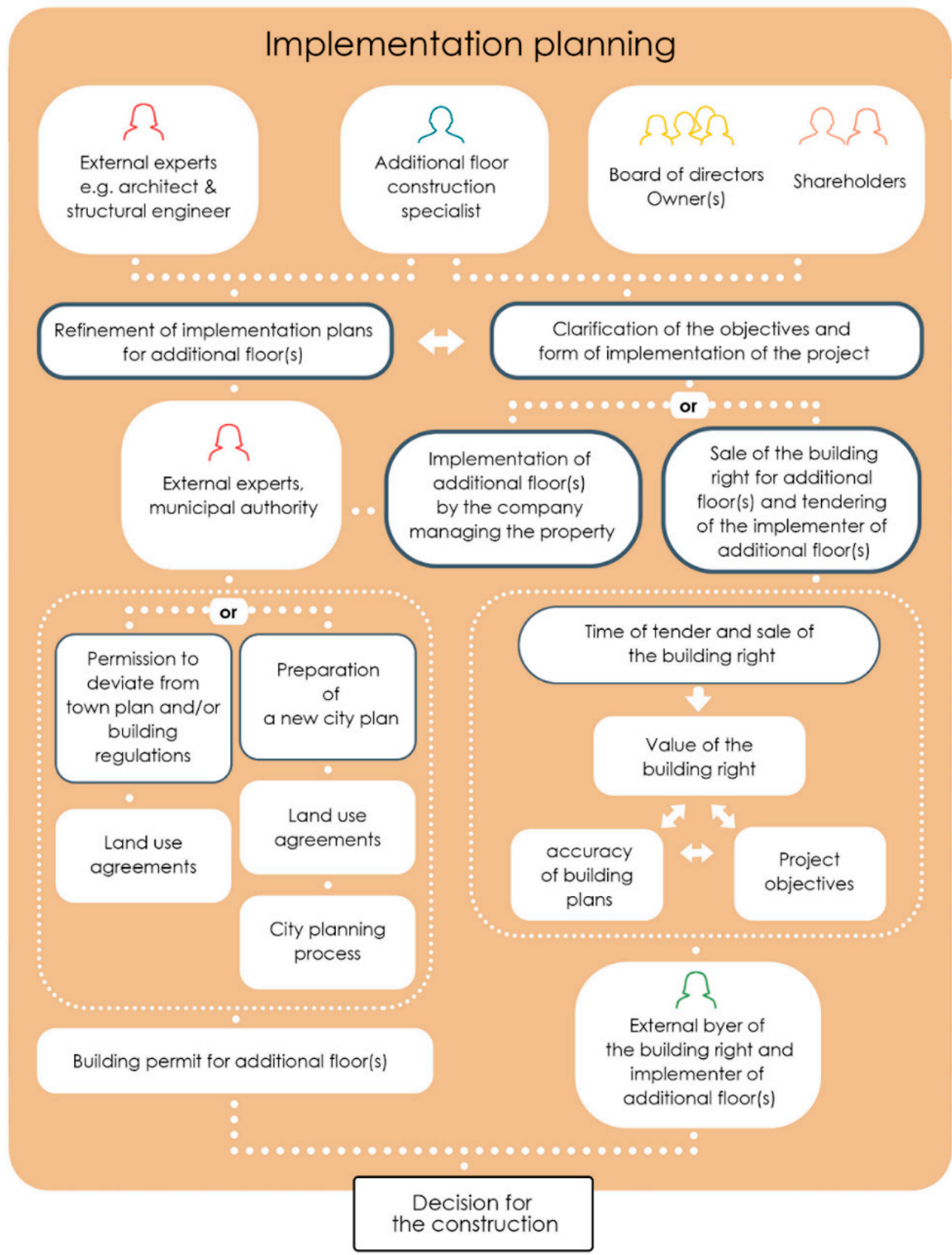

Figure 6. Implementation planning of additional floors.

\subsubsection{Construction Phase}

In the construction phase (Figure 7), critical considerations are as follows:

(a) effective flow of information: residents and stakeholders should be informed about the progress of the construction site, its schedules, and possible times when construction significantly impairs the residents' comfort of life; 
(b) appointing a representative: when planning critical milestones during the construction phase, such as demolition work, it is an effective method for a housing or real estate company representative to attend site meetings and negotiate available times for work to minimize inconvenience from construction to residents.

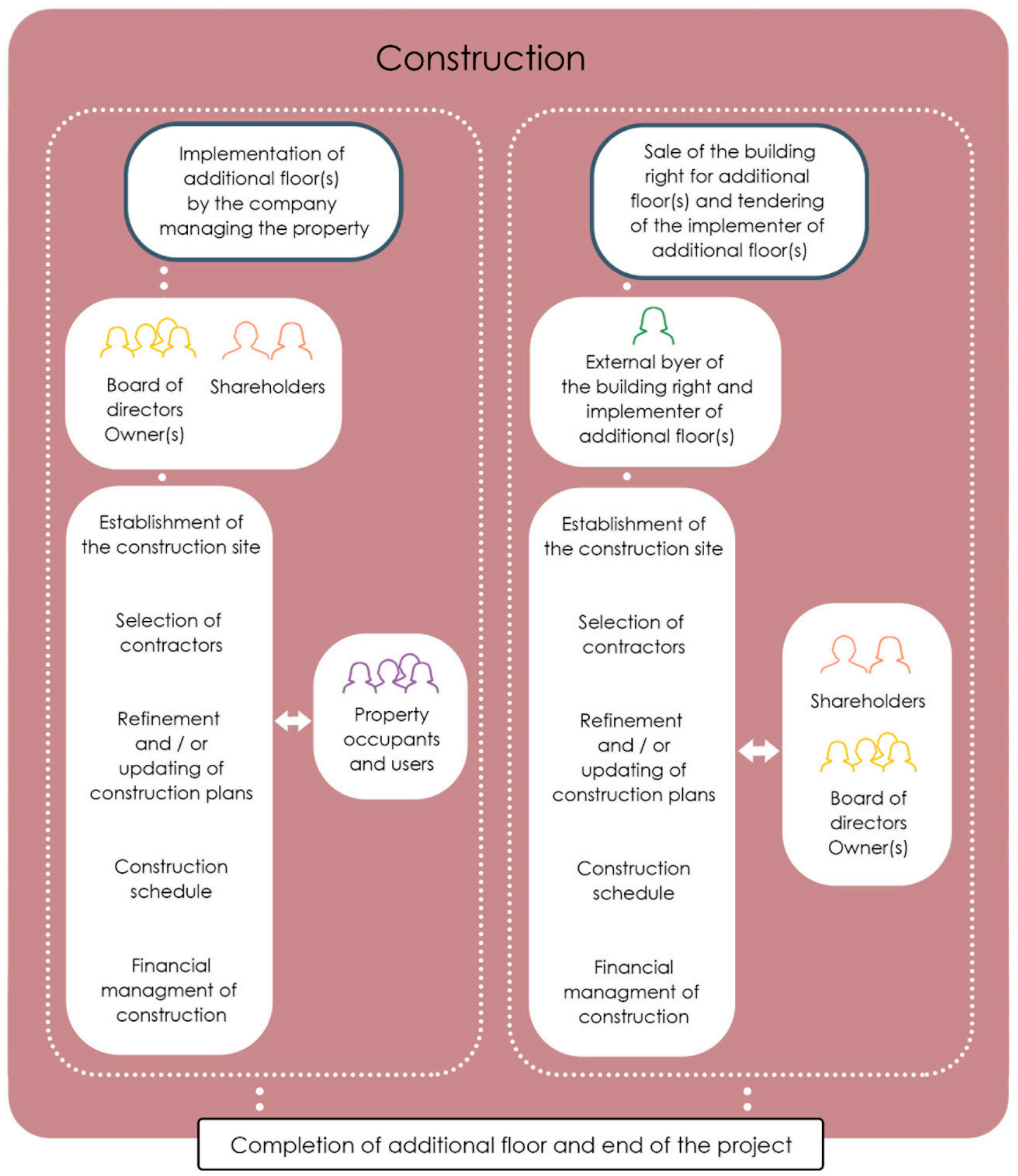

Figure 7. Construction of additional floors. 


\section{Discussion}

Due to the lack of literature, it was not possible to conduct a comprehensive discussion to provide information on the similarities and differences of the Finnish experience with practices from other countries.

During the feasibility study phase, (a) city planning issues such as relationship with surrounding buildings, shadow effect, and contacting the authorities; (b) additional parking spaces due to increased floor area and the number of residents considering relevant city authorities; (c) necessary information, documentation, and drawings to feed the project planning phase; (d) examination of the load-bearing capacity of the existing building by including a structural engineer specialized in renovation projects, and (e) new building regulations and rules e.g., retrofitting an elevator were considered as critical issues. Similarly, Soikkeli [14] drew attention to the importance of determining the increase in the number of additional parking lots due to the construction of an additional floor and thus determining how many additional parking areas should be built. Furthermore, according to Soikkeli [14], additional floors should be designed considering the structural performance of the existing building.

In the project planning phase, when designing a wooden extension to make additional floors economically profitable, the building regulations, especially the fire code, should be considered, as well as the sale of the building right including the subscription fee and tax issues. In a similar research project conducted by Soikkeli [14], compliance with the new fire code was particularly emphasized during the design phase of the renovation with wooden additional floors.

In the implementation planning phase, (a) the city plan change including the permission of the landowner and affecting the immediate surroundings of the property; (b) building rights, considering different tendering conditions in terms of an external developer, and (c) terms and conditions for the protection of the interests of the company managing the property were assessed as significant parameters.

In the construction phase, effective flow of information about the progress of construction between all interested parties, so as not to disturb the living comfort of residents, and when planning key milestones, by appointing a representative from the company to minimize discomfort from construction to residents were reported to be of critical importance. These resembled the findings in the study of Soikkeli [14], where the involvement of residents and apartment owners in planning plays an important role in the success of any renovation project.

\section{Conclusions}

This study aimed to examine the different phases of wooden additional floor construction projects broadly from the perspective of Finnish housing and real estate companies. In doing so, this paper sought to identify the benefits of wooden additional floor construction in Finland.

The main highlights obtained in this study regarding the four phases of wooden additional floor construction are as follows: During the feasibility study, the project planning is decided mainly by examining the condition of the property and possible development goals, as well as other critical issues such as parking lot reorganization and compliance with existing regulations. In the next phase, namely in the project planning, the implementation of additional floors is scrutinized in more detail, the construction costs and revenues, and the sale of the building rights come to the fore. As the next step, the implementation planning phase is often influenced by the city plan change, building rights, as well as terms and conditions related to the company managing the property. After the construction duties and responsibilities of the relevant parties are determined, the construction phase can be started. In this final phase, the residents are actively informed about the site regulations and the construction schedule.

All phases of wooden additional floor construction require commitment and investment as well as cooperation with construction specialists and housing or real estate pro- 
fessionals. Additional floor construction has potential for improvement, both in terms of construction technology and contracting mechanisms. Particularly regarding construction technology, the use of prefabricated timber solutions such as volumetric modular element design allows for rapid construction, which can reduce construction-related disturbances for building occupants and possibly increase the popularity and prevalence of wooden additional floors as in the case of in Finland. For example, in the Tampere region of Finland, the construction of wooden additional floors has become more common in the last decade, and the increased experience and precision in these projects is also reflected in the development of the contract-technical aspects.

In this sense, it is believed that the construction of wooden additional floors, which have many advantages in terms of the environment, economy, energy efficiency, and aesthetics, will become widespread in other countries as in Finland. Future studies of the potential extension of these projects in residential construction could examine the attitudes and interests of architects, structural engineers, city planners, and builders as they are critical actors in the construction industry.

Author Contributions: Conceptualization, M.K., H.E.I. and D.S.; methodology, M.K., H.E.I. and D.S.; software, H.E.I. and D.S.; formal analysis, M.K., H.E.I. and D.S.; investigation, M.K., H.E.I. and D.S.; data curation, M.K., H.E.I. and D.S.; writing—original draft preparation, H.E.I.; writing—review and editing, M.K., H.E.I. and D.S.; visualization, H.E.I. and D.S.; supervision, M.K. and H.E.I.; project administration, M.K.; funding acquisition M.K. and D.S. All authors have read and agreed to the published version of the manuscript.

Funding: This research was funded by The European Regional Development Fund (ERDF).

Institutional Review Board Statement: Not applicable.

Informed Consent Statement: Not applicable.

Data Availability Statement: Not applicable.

Conflicts of Interest: The authors declare no conflict of interest.

\section{Appendix A. Additional Floor Construction Guide Question Template}

\section{A. Questions to Board of Directors/Representatives of the Housing Company}

Mapping the progress of the project and the current situation

1. Where did the idea of extension/extension construction originate?

- How long was the matter discussed with the government?

- When were the other shareholders informed?

2. Is the additional floor project intended to finance the renovation of the building? If so, what kind of work will be funded?

3. Is the building to be upgraded located on land leased or owned by a housing association?

4. Has the property manager been contacted?

What role has the property manager taken and how has he/she instructed in the course of the project?

5. What decisions has the government made regarding the additional floor construction project?

6 . Has the board/property manager been in contact with other professionals or parties involved in the project?

What has survived from these parties?

- Neighbors

- City authorities

- Construction supervision

- Planning authorities

- Real estate lawyer 
- Builder consultant

- Civil engineers

- Architect

7. At what stage is the project now (how actively is it being taken forward)?

8. What issues or steps in the project make you think the most and seem to hold back the project?

Project burdens

9. Have preliminary cost calculations been made for the project? If so, what was the conclusion?

10. What are the possibilities and framework for adding/arranging car parking on your plot?

Can car parking be arranged in the public car park?

11. Has the adequacy of civil protection been considered?

12. Is there still a building right in the current formula, or does the project require a renewal of the current formula to be completed?

13. Have load-bearing examinations/studies of the structures of the existing building been carried out at the site?

14. Has there been any opposition to the project from the housing association's shareholders? If so, what are the reasons for the opposition?

The outcome of the project

15. Why is it desired to upgrade an existing building, instead of demolishing supplementary construction?

16. Does the material of the additional floors matter to the housing association?

17. Mass of additional layers

- Do you have architectural goals in mind?

(1-2 floors, renovate the mass/appearance of the existing building, more apartments with good views)

18. Any other comments regarding the progress/burdens/outcome of the project?

\section{B. Questions to Planning authority (City planner)}

\section{City strategy}

1. How does the city promote the construction of additional floors in its areas?

2. Does the city have clear quantified targets for additional floor construction?

3. Does the city offer financial subsidies for the construction of additional floors?

Does it offer relief for car parking, for example?

City planchange

4. How are deviations from the city plan normally handled for additional floor projects?

5 . How are changes in the layout of additional floor projects normally handled?

6. What does the city require from Housing/Real Estate Companies to initiate a plan change?

- Project plan

- Partners (Builder Consultant/Real Estate Lawyer)

- Builder/Contractor

\section{Land Use Agreements}

- What are the costs for a housing/real estate company?

\section{Land use agreements}

- What are the roles/obligations of housing associations about the zoning change?

9. How would you develop the zoning/permitting process for additional construction? 


\section{Other remarks}

10. What instructions would you give to a housing association considering an additional floor construction project?

11. Any other comments?

\section{Questions to Architect/Chief designer}

Project progress - contacting the housing company

1. How did the project start? At what point did As. Oy/Property Manager contact you?

2. What is the form of management of the additional layers?

(New As. Oy on top of the old or was it merged into the existing As. Oy)

3. How did the project progress after your hiring?

- Project plan

- Formula/derogation

- Negotiations between the builder/contractor

- Plans between As. Oy and the contractor

4. How did the communication between the housing company and the Architect/Chief Designer work?

5. How was the responsibility divided between the developer and As. Oy when planning additional floors/making permit documents? (In this context, by a builder I mean a third party who may have bought the right to build the additional floors and built/sold the apartments on the additional floors)

Combining additional floor construction and building renovation (If combined)

6. What kind of repairs were sought to be financed by the construction of additional floors and was they able to be financed?

7. Were the repairs done by the same contractor who also contracts the additional floors?

8. How did the repairs affect the negotiations on the sale of the right to build additional floors?

Other remarks

9. What do you think was particularly successful in the project?

What were the benefits of an architect's presence throughout the project?

10. Was there anything in the project that you would pay more attention to in the next extra floor project?

11. What initial information do you want the housing company to have before an architect/builder consultant is hired for the project?

12. If you were to guide a housing company, which is just starting to look at an additional floor construction project, what would you urge them to focus on?

13. Any other comments to be added?

D. Questions to the Housing manager

1. In which realized additional floor projects has the interviewee been involved?

2. What has been the material of the supporting frame of the additional layer objects?

Project progress

3. At what stage did the board of As. Oy contacted the property manager about the construction of additional floors or was the property manager in contact with the board of As. Oy?

4. How did the project progress?

- A need assessment

- Change of formula

- Negotiations between the builder/contractor

- Plans between As. Oy and the developer/contractor 


\section{Combiningadditional floor construction and building renovation}

5. What kind of repairs were sought to be financed by the construction of additional floors?

6. What repairs could be financed with the construction of additional floors?

7. Were the repairs done by the same contractor who also took care of the additional floors?

8. How did the repairs affect the negotiations for the sale of the right to build additional floors?

Other remarks

9. What is the role of the property manager in promoting the construction of additional floors?

10. What guidance would you give to the board of a housing association whose property manager does not have the resources or expertise to actively assist with the review of the additional floor project?

11. If you were to guide a housing company, which is just starting to look at an additional floor construction project, what would you urge them to focus on?

12. Any other comments to be added?

\section{E. Questions to the Additional floor construction consultant}

In which additional floor construction projects has the interviewee been involved?

Project progress - contacting the housing company

1. At what stage did the Housing Company/Property Manager contact the developer consultant?

What material had already been acquired?

2. How did the project progress after hiring a construction consultant?

- Change of formula

- Negotiations between the builder/contractor

- Plans between housing company and the Developer/Contractor

3. How did the communication between As. Oy and the developer consultant work?

4. How did the negotiations between the different actors in the project succeed?

5. How was the responsibility divided between the developer of the additional floors and the housing association when working with the planning authorities?

6. How was the responsibility divided between the developer and the housing association when planning the additional floors/making the permit documents?

\section{F. Questions to Builders/Contractors}

Organizational background

1. Completed additional floor projects

2. The organization's future expectations for additional floor construction

Project progress

3. At what stage of additional floor construction is it good for the housing company to approach the builder/contractor (before after the layout change?)

4. What clarifications/plans would you like the Housing Company to have when contacting the developer?

5. If renovation/repair work has been carried out in connection with the additional floors, how have the contracts been divided, and has it affected the sale price of the building right?

6. Things to consider for condominiums during the construction phase?

Other notes

10. Any other remarks/tips for housing companies embarking on an additional floor construction project?

11. Other remarks on additional floor construction and its promotion in Finland? 


\section{References}

1. European Commission. Energy Roadmap 2050 Impact Assessment and Scenario Analysis, Brussels. 2011. Available online: https:/ / ec.europa.eu/energy/sites/ener/files/documents/roadmap2050_ia_20120430_en_0.pdf (accessed on 15 July 2021).

2. Energy Policies of The International Energy Agency (IEA) Countries: Finland 2018 Review. 2018. Available online: https: //www.connaissancedesenergies.org/sites/default/files/pdf-actualites/situation_energetique_de_la_finlande.pdf (accessed on 15 July 2021).

3. Kuittinen, M.; Häkkinen, T. Reduced carbon footprints of buildings: New Finnish standards and assessments. Build. Cities 2020, 1, 182-197. [CrossRef]

4. Simson, R.; Fadejev, J.; Kurnitski, J.; Kesti, J.; Lautso, P. Assessment of Retrofit Measures for Industrial Halls: Energy Efficiency and Renovation Budget Estimation. Energy Procedia 2016, 96, 124-133. [CrossRef]

5. European Commission. Long-Term Renovation Strategy 2020-2050 Finland, Report according to Article 2a of Directive (2010/31/EU) on the Energy Performance of Buildings, as Amended by Directive 2018/844/EU. 10 March 2020. Available online: https:/ / ec.europa.eu/energy/sites/default/files/documents/fi_2020_trs_en.pdf (accessed on 15 July 2021).

6. Kaasalainen, T.; Huuhka, S. Homogenous homes of Finland: Standard flats in non-standardized blocks. Build. Res. Inform. 2015, 44, 229-247. [CrossRef]

7. Hirvonena, J.; Jokisaloa, J.; Heljo, J.; Kosonena, R. Towards the EU emissions targets of 2050: Optimal energy renovation measures of Finnish apartment buildings. Int. J. Sustain. Energy 2018, 38, 1-24. [CrossRef]

8. KTI Finland. The Finnish Property Market I 2019. Available online: https://kti.fi/wp-content/uploads/The-Finnish-PropertyMarket-2019.pdf (accessed on 15 July 2021).

9. Farahani, A.S. Maintenance, Renovation and Energy Efficiency in the Swedish Multi-Family Housing Market, The Division of Building Services Engineering; Chalmers University of Technology: Gothenburg, Sweden, 2017; Available online: https://core.ac.uk/ download/pdf/198056482.pdf (accessed on 15 July 2021).

10. Official Statistics of Finland (OSF). Homeowners and Housing Companies Repaired by EUR 6.0 Billion in 2019. 2019. Available online: http://www.stat.fi/til/kora/2019/01/kora_2019_01_2020-06-11_tie_001_fi.html\%20 (accessed on 15 July 2021).

11. Ferrante, A.; Prati, D.; Fotopoulou, A. Triple A-Reno: Attractive, Acceptable and Affordable Deep Renovation by a Consumers Orientated and Performance Evidence Based Approach. WP4-Task 4.2 Analysis and Design of the Business Module; Huygen Installatie Adviseurs: Maastricht, The Netherlands, 2018.

12. Mills, B.; Schleich, J. Residential energy-efficient technology adoption, energy conservation, knowledge, and attitudes: An analysis of European countries. Energy Policy 2012, 49, 616-628. [CrossRef]

13. Janda, K.B. Building communities and social potential: Between and beyond organizations and individuals in commercial properties. Energy Policy 2014, 67, 48-55. [CrossRef]

14. Soikkeli, A. Additional floors in old apartment blocks. Energy Procedia 2016, 96, 815-823. [CrossRef]

15. D'Oca, S.; Ferrante, A.; Ferrer, C.; Pernetti, R.; Gralka, A.; Sebastian, R.; Veld, P. Technical, Financial, and Social Barriers and Challenges in Deep Building Renovation: Integration of Lessons Learned from the H2020 Cluster Projects. Buildings 2018, 8, 174. [CrossRef]

16. Jurelionis, A.; Šeduikyte, L. Multifamily building refurbishment process in Lithuania and other European countries. In Proceedings of the 10th International Conference Modern Building Materials, Structures and Techniques, Vilnius, Lithuania, 19-21 May 2010; pp. 106-111.

17. Botici, A.A.; Ungureanu, V.; Ciutina, A.; Botici, A.; Dubina, D. Sustainable retrofitting of large panel prefabricated concrete residential buildings. In Proceedings of the Central Europe towards Sustainable Building 2013 Conference-Sustainable Building and Refurbishment for Next Generations, Prague, Czech Republic, 26-28 June 2013.

18. Matic, D.; Calzada, J.R.; Eric, M.; Babin, M. Economically feasible energy refurbishment of prefabricated building in Belgrade. Energy Build. 2015, 98, 74-81. [CrossRef]

19. Myers, F.; Fullera, R.; Crawford, R.H. The potential to reduce the embodied energy in construction through the use of renewable materials. In Proceedings of the ASA2012: The 46th Annual Conference of the Architectural Science Association (Formerly ANZAScA)—Building on Knowledge: Theory and Practice, Gold Coast, Australia, 14-16 November 2012.

20. Construction Industry Progress towards Sustainability with Renewable Materials. Recycling Magazine. 2020. Available online: https:/ / www.recycling-magazine.com/2020/04/14/construction-industry-progress-towards-sustainability-with-renewablematerials / (accessed on 15 July 2021).

21. CWC. Energy and the Environment in Residential Construction; Sustainable Building Series No.1; The Canadian Wood Council: Ottawa, ON, Canada, 2007.

22. Green, M. The Case for Tall Buildings: How Mass Timber Offers a Safe, Economical, and Environmentally Friendly Alternative for Tall Building Structures; MGB Architecture and Design: Vancouver, BC, Canada; Toronto, ON, Canada, 2012.

23. Wang, L.; Toppinen, A.; Juslin, H. Use of Wood in Green Building: A Study of Expert Perspectives from the UK. J. Clean. Prod. 2014, 65, 350-361. [CrossRef]

24. Gustavsson, L.; Joelsson, A.; Sathre, R. Life cycle primary energy use and carbon emission of an eight-storey wood-framed apartment building. Energy Build. 2010, 42, 230-242. [CrossRef]

25. Sandberg, K.; Orskaug, T.; Andersson, A. Prefabricated Wood Elements for Sustainable Renovation of Residential Building Façades. Energy Procedia 2016, 96, 756-767. [CrossRef] 
26. Niederwestberg, J.; Zhou, J.; Chui, Y.-H. Mechanical Properties of Innovative, Multi-Layer Composite Laminated Panels. Buildings 2018, 8, 142. [CrossRef]

27. Rahman, M.D.T.; Ashraf, M.; Ghabraie, K.; Subhani, M. Evaluating Timoshenko Method for Analyzing CLT under Out-of-Plane Loading. Buildings 2020, 10, 184. [CrossRef]

28. Edwards, R.; Holland, J. What Is Qualitative Interviewing? Bloomsbury: London, UK, 2013.

29. Luoma-Halkola, P. Technical Prefabricated Element Solutions and Cost Effects of Raising the Floor Number of Suburban Buildings in Infill Construction. Master's Thesis, Department of Civil Engineering, Aalto University, Espoo, Finland, 2013.

30. Hilli-Lukkarinen, M. Architectural Planning in the Elevation of Buildings-Case Analysis in Tampere. Master's Thesis, School of Architecture, Tampere University, Tampere, Finland, 2019.

31. Huuhka, S.; Vainio, T.; Moisio, M.; Lampinen, E.; Knuuttinen, M.; Bashmakov, S.; Köliö, A.; Lahdensivu, J.; Ala-Kotila, P.; Lahdenperä, P. To Demolish or to Repair? Carbon Footprint Impacts, Life Cycle Costs and Steering Instruments, Publications of the Ministry of the Environment 2021:9. Built Environment. 2021. Available online: https://julkaisut.valtioneuvosto.fi/ bitstream/handle/10024/162862/YM_2021_9.pdf?sequence=4\&isAllowed=y (accessed on 15 July 2021).

32. Panschin, A. Costs and Benefits of Extension Construction-The Perspective of the City and the Housing Association; Environment and Zoning Agency: City of Turku, Finland, 2009; p. 57.

33. Bojić, M.; Miletić, M.; Malešević, J.; Djordjević, S. Influence of additional storey construction to space heating of a residential building. Energy Build. 2012, 54, 511-518. [CrossRef]

34. Soikkeli, A.; Koisio-Kanttila, J.; Heikkinen, M. Korjaa ja Korota-Malleja ja ide-oita Kerrostalojen Korjaamiseen ja Lisäkerrosten Rakentamiseen (Repair and Upgrade-Models and Ideas for Repairing Apartment Buildings and Building Additional Floors); Faculty of Architecture, University of Oulu: Oulu, Finland, 2015; Available online: http:/ /jultika.oulu.fi/files/isbn9789526208565.pdf (accessed on 15 July 2021).

35. Kamari, A.; Corrao, R.; Kirkegaard, P.H. Sustainability focused decision-making in building renovation. Int. J. Sustain. Built Environ. 2017, 6, 330-350. [CrossRef]

36. Lehmann, S.; Reinschmidt, A.; Mustillo, L. Forest \& Wood Products Australia, Transition strategies: Accelerating Social Acceptance and Removing the Barriers to Prefabricated Multi-storey Timber Urban Infill Developments in Australia Using CLT Construction Systems, Project Number: PNE293-1213. December 2012. Available online: https:/ /www.fwpa.com.au/images/marketaccess/ PNE293-1213_FWPA-UniSA_CLT_Report_0.pdf (accessed on 20 July 2021).

37. Soikkeli, A. Possibilities in the Renovation of Suburban Apartment Buildings. Case: Porvoonportti. In Improving the Quality of Suburban Building Stock; COST Action TU0701: Ferrara, Italy, 2012; pp. 127-140.

38. Churkina, G.; Organschi, A.; Reyer, C.P.O.; Ruff, A.; Vinke, K.; Liu, Z.; Reck, B.K.; Graedel, T.E.; Schellnhuber, H.J. Buildings as a Global Carbon Sink, Nature Sustainability. 2020. Available online: https://www.nature.com/articles/s41893-019-0462-4 (accessed on 15 July 2021).

39. Hart, J.; D'Amico, B.; Pomponi, F. Whole-life embodied carbon in multistory buildings Steel, concrete and timber structures. J. Ind. Ecol. 2021, 25, 403-418. [CrossRef]

40. Robati, M.; Oldfield, P.; Nezhad, A.A.; Carmichael, D.G.; Kuru, A. Carbon value engineering: A framework for integrating embodied carbon and cost reduction strategies in building design. Build. Environ. 2021, 192, 107620. [CrossRef]

41. Ruuska, A.; Häkkinen, T. Material efficiency of building construction. Buildings 2014, 4, 266-294. [CrossRef]

42. Franzini, F.; Toivonen, R.; Toppinen, A. Why Not Wood? Benefits and Barriers of Wood as a Multistory Construction Material: Perceptions of Municipal Civil Servants from Finland. Buildings 2018, 8, 159. [CrossRef]

43. Høibø, O.; Hansen, E.; Nybakk, E. Building material preferences with a focus on wood in urban housing: Durability and environmental impacts. Can. J. For. Res. 2015, 45, 1617-1627. [CrossRef]

44. Švajlenka, J.; Kozlovská, M. Construction-Technical Specifics of a Prefabricated Wood Construction System. Ad Alta J. Interdiscip. Multidiscip. Res. 2020, 10, 373-376.

45. Gosselin, A.; Cimon, Y.; Lehoux, N.; Blanchet, P. Main Features of the Timber Structure Building Industry Business Models. Buildings 2021, 11, 170. [CrossRef]

46. Orlowski, K. Automated manufacturing for timber-based panelised wall systems. Autom. Constr. 2020, 109, 102988. [CrossRef]

47. Urban Planning Board (Kaupunkisuunnittelulautakunta). Instructions for Calculating the Number of Parking Spaces on Residential Plots (Asuintonttien pysäköintipaikkamäärien lasken-taohjeet). City of Helsinki, Urban Planning Board. 2015. Available online: https:/ /dev.hel.fi/paatokset/asia/hel-2015-010556/ (accessed on 15 July 2021). 